\title{
La-doped $\mathrm{Ba} 0.5 \mathrm{Sr} 0.5 \mathrm{Co0} .8 \mathrm{Fe} 0.2 \mathrm{O} 3$ - as cathode for protonic-conducting solid oxide fuel cells with enhanced structure stability
}

Xie, Yun; Hu, Xueyu; Shi, Nai; Peng, Ranran; Chen, Ming; Xia, Changrong

Published in:

ECS Transactions

Link to article, DOI:

$10.1149 / 10301.1525$ ecst

Publication date:

2021

Document Version

Peer reviewed version

Link back to DTU Orbit

Citation (APA):

Xie, Y., Hu, X., Shi, N., Peng, R., Chen, M., \& Xia, C. (2021). La-doped $\mathrm{Ba}{ }_{\mathrm{Sr}} \mathrm{Co}_{0} \mathrm{Fe}_{2} \mathrm{O}_{3}$ as cathode for protonic-conducting solid oxide fuel cells with enhanced structure stability. EQ 5 Transactions, ${ }^{3}, 03(1), 1525-$ 1535. https://doi.org/10.1149/10301.1525ecst

\section{General rights}

Copyright and moral rights for the publications made accessible in the public portal are retained by the authors and/or other copyright owners and it is a condition of accessing publications that users recognise and abide by the legal requirements associated with these rights.

- Users may download and print one copy of any publication from the public portal for the purpose of private study or research.

- You may not further distribute the material or use it for any profit-making activity or commercial gain

- You may freely distribute the URL identifying the publication in the public portal 


\section{La-doped Ba0.5Sr0.5 $\mathrm{Con}_{0.8} \mathrm{Fe}_{0.2} \mathrm{O}_{3-\delta}$ as Cathode for Protonic-conducting Solid Oxide}

\section{Fuel Cells with Enhanced Structure Stability}

Yun Xie ${ }^{\mathrm{a}, \mathrm{b}}$, Xueyu Hu${ }^{\mathrm{a}}$, Nai Shi ${ }^{\mathrm{a}, \mathrm{c}}$, Ranran Peng ${ }^{\mathrm{a}^{*}}$, Ming Chen ${ }^{\mathrm{b}^{*}}$, and Changrong Xia ${ }^{\mathrm{a}}$

${ }^{a}$ CAS Key Laboratory of Materials for Energy Conversion, Department of Materials Science and Engineering, University of Science and Technology of China, Hefei, 230026 Anhui, China.

${ }^{\mathrm{b}}$ Department of Energy Conversion and Storage, Technical University of Denmark, Anker Engelunds Vej 1, 2800 Kgs. Lyngby, Denmark.

${ }^{\mathrm{c}}$ INAMORI Frontier Research Center, Kyushu University 744 Motooka, Fukuoka 8190395, Japan

As a highly efficient energy conversion device, proton-conducting solid oxide fuel cells (PCFCs) have attracted intensive attention. Unfortunately, its practical application is limited by the catalytic activity and stability of the cathode. Here, we report a novel electrochemical catalyst of 10 mol.\% La modified $\mathrm{Ba}_{0.5} \mathrm{Sr}_{0.5} \mathrm{Co}_{0.8} \mathrm{Fe}_{0.2} \mathrm{O}_{3-\delta}$ cathode, showing much improved stability under typical PCFCs working conditions. XRD patterns confirm that $\mathrm{La}_{0.1} \mathrm{Ba}_{0.4} \mathrm{Sr}_{0.5} \mathrm{Co}_{0.8} \mathrm{Fe}_{0.2} \mathrm{O}_{3-\delta}$ maintains cubic structure after treated in humid air or $10 \% \mathrm{H}_{2} \mathrm{O}-90 \% \mathrm{~N}_{2}$. In addition, $\mathrm{La}_{0.1} \mathrm{Ba}_{0.4} \mathrm{Sr}_{0.5} \mathrm{Co}_{0.8} \mathrm{Fe}_{0.2} \mathrm{O}_{3-\delta}$ also demonstrates outstanding oxygen transport properties with a chemical surface exchange coefficient of $2.3 * 10^{-3} \mathrm{~cm} \mathrm{~s}^{-1}$ at $700{ }^{\circ} \mathrm{C}$, and the assembled single cells using this novel material present a minimal polarization resistance of $0.05 \Omega$ $\mathrm{cm}^{2}$ at $700{ }^{\circ} \mathrm{C}$. The high stability and great electrochemical performance of $\mathrm{La}_{0.1} \mathrm{Ba}_{0.4} \mathrm{Sr}_{0.5} \mathrm{Co}_{0.8} \mathrm{Fe}_{0.2} \mathrm{O}_{3-\delta}$ may result from the stronger interaction in the $\mathrm{La}-\mathrm{O}$ bond than in $\mathrm{Ba}-\mathrm{O}$. This work provides a strategy to modify materials properties via optimizing the interaction between metal and oxygen ions in the oxide lattice.

\section{Introduction}

Regarded as one of the clean and efficient energy conversion devices, proton-conducting solid oxide fuel cells (PCFCs) have drawn increasing attention and demonstrated potential application at intermediate temperatures $\left(500-700^{\circ} \mathrm{C}\right)(1,2)$. Unlike oxygen ion-conducting SOFCs (O-SOFCs), in PCFCs, water is formed on the cathode side. This can avoid mixing of fuels and reaction products, and can hence reduce the anode degradation caused by formation of water (3). Unfortunately, it is generally believed that the poor activity and stability of cathode greatly limit its commercial application (4) at low operating temperatures. As shown in Equation 1, oxygen reduction reaction (ORR) in cathode of PCFCs involve both protons and electrons (5).

$$
4 \mathrm{H}^{+}+\mathrm{O}_{2}+4 \mathrm{e}^{-}=2 \mathrm{H}_{2} \mathrm{O}
$$


A rational method to prepare high performing cathodes is to use composite cathodes composed of both electrolyte materials and mixed oxygen ion-electron conductors (MIEC) (6). Considerable effort has been made for electrolytes with high proton conductivity and stability (7-10). The other challenge is to develop highly efficient and stable MIEC electrocatalysts. $\mathrm{Ba}_{0.5} \mathrm{Sr}_{0.5} \mathrm{Co}_{0.8} \mathrm{Fe}_{0.2} \mathrm{O}_{3-\delta}$ (BSCF) is regarded as an excellent oxygen reduction reaction electrocatalyst due to its superior oxygen transport properties (11). As we previously reported, the oxygen chemical bulk diffusion coefficient, $D_{\text {chem }}$, and chemical oxygen surface exchange coefficient, $k_{\text {chem }}$, of BSCF at $700{ }^{\circ} \mathrm{C}$ are $2 * 10^{-5} \mathrm{~cm}^{2} \mathrm{~S}^{-}$ ${ }^{1}$ and $4^{*} 10^{-4} \mathrm{~cm} \mathrm{~S}^{-1}$, respectively (12). Both the bulk diffusion coefficient and the surface exchange coefficient of BSCF are about one order of magnitude higher than those of classic electrocatalyst $\mathrm{La}_{0.6} \mathrm{Sr}_{0.4} \mathrm{Co}_{0.8} \mathrm{Fe}_{0.2} \mathrm{O}_{3-\delta}$ (LSCF) at the same temperature: $6.4 * 10^{-6} \mathrm{~cm}^{2} \mathrm{~S}^{-1}$ for $k_{\text {chem }}$ and $1.3^{*} 10^{-5} \mathrm{~cm} \mathrm{~S}^{-1}$ for $D_{\text {chem }}$, respectively (13), and are comparable with those of $\mathrm{PrBaCo}_{2} \mathrm{O}_{5+\delta}$ which is the state-of-the-art electrocatalyst for PCFCs cathodes $\left(1 * 10^{-5} \mathrm{~cm}^{-2}\right.$ $\mathrm{S}^{-1}$ for $D_{\text {chem }}$ and $1^{*} 10^{-4} \mathrm{~cm} \mathrm{~S}^{-1}$ for $k_{\text {chem }}$, respectively) $(2,14)$. Therefore, BSCF is an excellent ORR electrocatalyst. Especially, at intermediate temperatures, it still preserves high oxygen transport performance, which makes it a potential cathode for PCFCs.

Nevertheless, the application of BSCF is largely hindered by its structure instability at typical PCFCs working temperatures $(15,16)$. At temperatures below $800{ }^{\circ} \mathrm{C}, \mathrm{BSCF}$ is likely to suffer a structure transition from the corner-shared cubic phase to the face-shared hexagonal phase. This change will weaken the connection between electrolyte and cathode, and reduce the oxygen transport performance of BSCF, resulting in the degradation of fuel cells. Furthermore, this transformation will be accelerated by water and carbon dioxide (18), which exist inevitably in the cathode compartment of PCFCs (17) and which also retards the ORR kinetics due to their competitive adsorption on BSCF (in competition with oxygen adsorption) (18). To improve the structural and chemical stability, Tsvetkov et al. reported that using less reducible (univalent) elements on B-site can improve the surface stability, but at the cost of redox catalytic capability and electronic conductivity, and thus, leading to decreased power density of single cells (19). An alternative method is to partially replace the A-site elements with higher acidity elements to improve the stability of oxides in humid atmosphere (20). However, Steven et al. found out that the structure stability of $\mathrm{SrCo}_{0.8} \mathrm{Fe}_{0.2} \mathrm{O}_{3-\delta}$ is inferior to that of $\mathrm{BSCF}$, even though strontium presents higher acidity (21). We found that this instability may be due to the fact that the interaction between $\mathrm{Sr}$ and $\mathrm{O}$ in the $\mathrm{Sr}-\mathrm{O}$ bond (bonding energy: $454 \mathrm{~kJ} \mathrm{~mol}^{-1}$ ) is weaker than in Ba-O (bonding energy: $563 \mathrm{~kJ} \mathrm{~mol}^{-1}$ ) (22). The Sr-O interaction is not strong enough to inhibit the transformation of cubic structure. Inspired by this, we propose that the interaction between A-site metal and oxygen has an important effect on the structure stability of BSCF.

In this work, lanthanum is used to partially replace barium to improve the structure stability of BSCF. Lanthanum has a stronger interaction with oxygen ions (bonding energy: $\left.799 \mathrm{~kJ} \mathrm{~mol}^{-1}\right)$ than barium $\left(563 \mathrm{~kJ} \mathrm{~mol}^{-1}\right)$, and hence can inhibit the release of oxygen, and thus hinder the structural transformation from the corner-shared cubic phase to the faceshared hexagonal phase. It should be noted that the ionic radius of $\mathrm{La}^{3+}(1.36 \AA)$ is smaller than that of $\mathrm{Ba}^{2+}(1.61 \AA)$, which can alleviate the structural distortion and instability caused by the large difference in ionic radius between $\mathrm{Ba}^{2+}$ and $\mathrm{Co}^{3+}(0.61 \AA) / \mathrm{Fe}^{3+}(0.55$ $\AA$ ). To confirm our hypothesis, crystal structure, material stability, oxygen transport properties, and catalytic activity of BSCF without and with introducing lanthanum were investigated. If successful, this work will provide a strategy to modify materials properties via optimizing the interaction between metal and oxygen ions in the oxide lattice. 


\section{Experiment}

\subsection{Materials Synthesis}

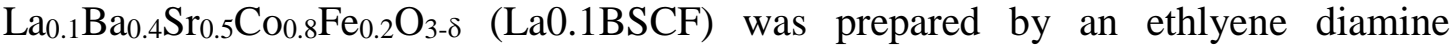
tetraacetic acid (EDTA)-citric acid method. Stoichiometric amounts of $\mathrm{La}\left(\mathrm{NO}_{3}\right)_{3}$, $\mathrm{Ba}\left(\mathrm{NO}_{3}\right)_{3}, \mathrm{Sr}\left(\mathrm{NO}_{3}\right)_{2}, \mathrm{Co}\left(\mathrm{NO}_{3}\right)_{2} \cdot 6 \mathrm{H}_{2} \mathrm{O}$, and $\mathrm{Fe}\left(\mathrm{NO}_{3}\right)_{3} \cdot 9 \mathrm{H}_{2} \mathrm{O}$ were dissolved in deionized water with moderate nitric acid. Citric acid and EDTA were added as complexing agent, and the molar ratio of metal cations to citric acid and EDTA was set as 1:2:1. After adjusting $\mathrm{pH}$ to about 7 using ammonia, the solution was stirred using a magnetic stirrer at $70{ }^{\circ} \mathrm{C}$ for 2 hours. The solution was then heated on a hot plate, to evaporate all the water and self-ignited to ashes. The ashes were heat treated at $1000^{\circ} \mathrm{C}$ in air for 2 hours to obtain a good crystallization. BSCF was prepared with a similar procedure. Powders of $\mathrm{BaZr}_{0.3} \mathrm{Ce}_{0.5} \mathrm{Y}_{0.2} \mathrm{O}_{3-\delta}$ (BZCY) and $\mathrm{NiO}$ were synthesized by the processes previously reported $(23,24)$. All the chemicals used in this work were purchased from Sinopharm Chemical Reagent Co., Ltd, China.

\subsection{Transport Properties Measurement}

The green strip samples $\left(\sim 30.00 * 5.50 * 0.50 \mathrm{~mm}^{3}\right)$ were prepared by uniaxial dry pressing with a stainless steel mold. Certain amounts of the as-prepared powders were pressed in the mold at $300 \mathrm{MPa}$ for about 30 seconds. The green strip samples were sintered at $1150{ }^{\circ} \mathrm{C}$ in ambient air for 5 hours to obtain dense samples. The relative density determined by the Archimedes drainage method was above $95 \%$, fulfilling the requirement for further measurement. The electrical conductivity was measured from 550 to $700{ }^{\circ} \mathrm{C}$ using a DC four-probe method with a measurement system consisting of a digital mutimeter (Keithley 2001-785D). While the oxygen pressure was abruptly changed from 0.21 to $1 \mathrm{~atm}$, the change of electrical conductivity with time was recorded until reaching equilibrium at each temperature. A gas flow rate of $200 \mathrm{ml} \mathrm{min}^{-1}$ was adopted to ensure a fast gas switching. This electrical conductivity relaxation (ECR) method was used to investigate the oxygen transport properties.

\subsection{Phase and Microstructure Characterization}

X-ray diffraction (XRD) measurements were performed using a Philips X'pert PROS diffractometer with $\mathrm{Cu}-\mathrm{K}_{\alpha}$ radiation $(\lambda=1.5418 \AA)$, in the range of $20-80^{\circ}$ with $0.02^{\circ}$ step size and $2^{\circ} \mathrm{min}^{-1}$. The microstructures were investigated via scanning electron microscopy (SEM, JSM-6700F, JEOL). A high resolution transmission electron microscopy (HRTEM, JEM-2010, $200 \mathrm{kV}$ ) equipped with an energy dispersive spectroscopy (EDS) was used to investigate the elemental distributions. X-ray photoelectron spectroscopy (XPS, Thermo ESCALAB 250) was used to confirm the existence of lanthanum. The thermal expansion behavior in air was studied using a dilatometer (Netzsch DIL 402C) with a heating rate of $10{ }^{\circ} \mathrm{C} \mathrm{min}{ }^{-1}$ from 50 to $1000{ }^{\circ} \mathrm{C}$. The oxygen temperature programmed desorption $\left(\mathrm{O}_{2}-\right.$ $\mathrm{TPD}$ ) and $\mathrm{CO}_{2}$-TPD measurements were performed using a Thermo Electron Corporation TPDRO 1100 flow apparatus.

\subsection{Cell Fabrication and Electrochemical Test}


Single cells with a configuration NiO-BZCY /BZCY/ La0.1BSCF-BZCY were fabricated using the NiO-BZCY anode as the substrate (i.e. mechanical support). The composite NiO-BZCY anode was prepared by first mixing $\mathrm{NiO}, \mathrm{BZCY}$ and polymethylmethacrylate (PMMA) with a weight ratio of 65:35:10, and afterwards uniaxial co-pressing to obtain green bodies consisting of anode substrate and electrolyte. The green bodies were sintered in air at $1350{ }^{\circ} \mathrm{C}$ for 5 hours. A composite cathode slurry, consisting of La0.1BSCF, BZCY and home-made binder in a weight ratio of 6:4:15, was applied on to the electrolyte surface by brush painting and subsequent sintering at $1000{ }^{\circ} \mathrm{C}$ in air for 2 hours with a heating and cooling rate of $3{ }^{\circ} \mathrm{C} \mathrm{min}^{-1}$, to form a porous cathode.

The cell performance in terms of $I-P$ - $V$ curves was investigated by a home-made testing system with humid $\mathrm{H}_{2}\left(3 \% \mathrm{H}_{2} \mathrm{O}\right)$ as fuel and ambient air as oxidant, using an electrochemistry workstation (Solartron 1287 potentiostat). AC impedance spectra of the single cells were obtained by an electrochemistry workstation (Solartron 1260 frequency response analyzer) with an $\mathrm{AC}$ perturbation signal of $20 \mathrm{mV}$ in a frequency range from 0.1 $\mathrm{Hz}$ to $1 \mathrm{MHz}$.

\section{Results and Discussions}

\subsection{Phase Stability and Crystal Structure}

(a)

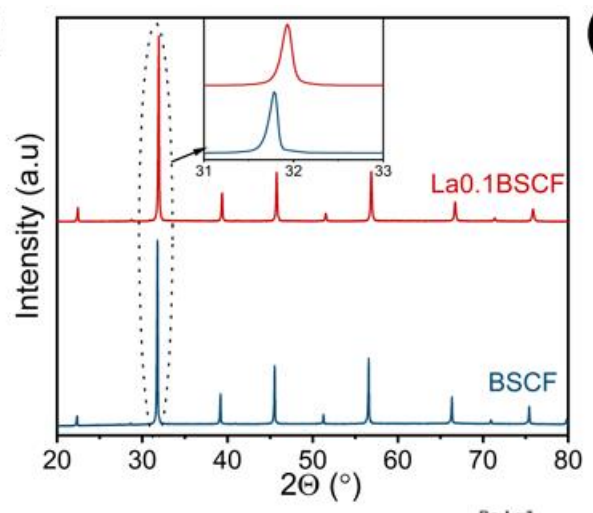

(b)

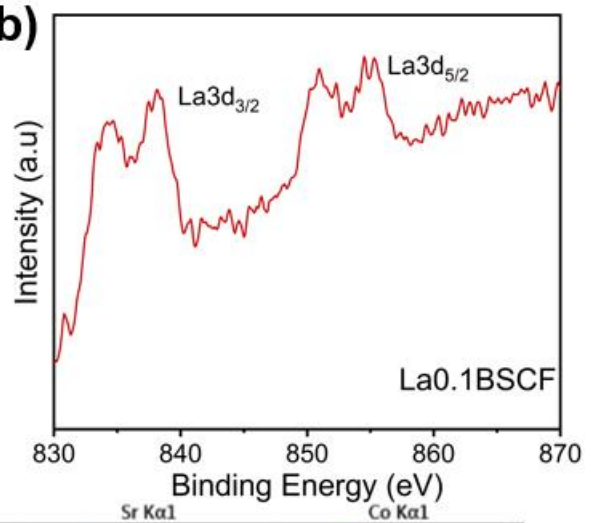

(c)
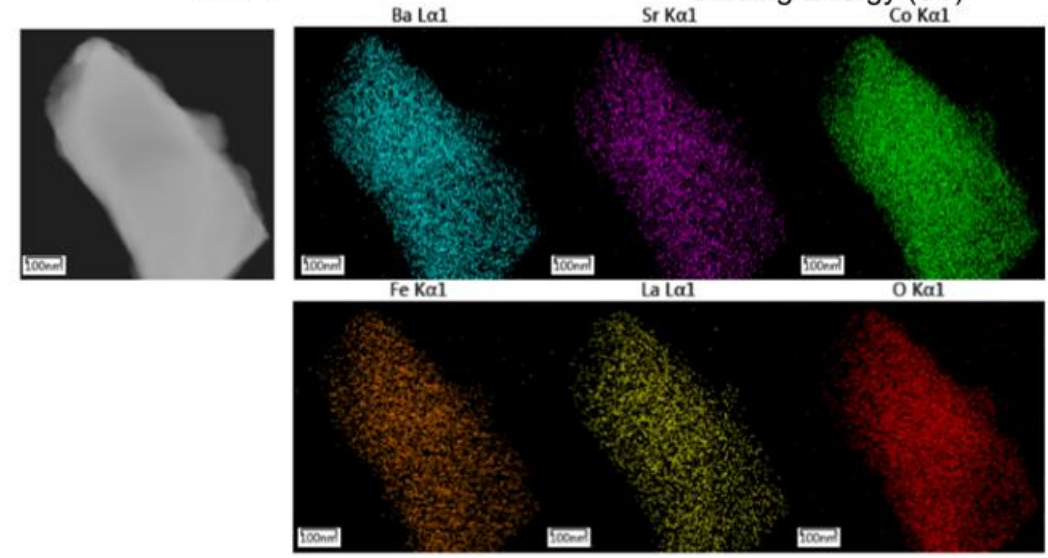

Figure 1 (a) XRD patterns for the as-prepared BSCF and La0.1BSCF powder; (b) XPS spectrum of La 3d obtained on the La0.1BSCF powder, and (c) TEM image and corresponding EDS map of a La0.1BSCF particle.

Figure 1a shows the XRD patterns for the as-prepared La0.1BSCF and BSCF powder. In both patterns, all peaks match well with those of the cubic perovskite phase, and no extra 
peaks corresponding to any secondary phase are detected, indicating that the two samples are phase pure and have the same crystal structure. The magnified pattern at 31-33 suggests that the peak position has a slight shift towards high angle due to introduction of lanthanum into the crystal lattice. This shift indicates that La0.1BSCF has a smaller crystal lattice than BSCF, which should be ascribed to the smaller ionic radius of $\mathrm{La}^{3+}\left(\mathrm{r}_{\mathrm{La} 3+}: 1.36\right.$ $\AA$, $\mathrm{r}_{\mathrm{Ba} 2+}: 1.61 \AA$ ). The XPS spectrum for La $3 \mathrm{~d}$ in Figure $1 \mathrm{~b}$ further confirms that lanthanum is successfully introduced into BSCF. The TEM image and the corresponding energydispersive X-ray (EDS) elemental map shown in Figure 1c indicate all the elements are distributed uniformly without obvious segregation.

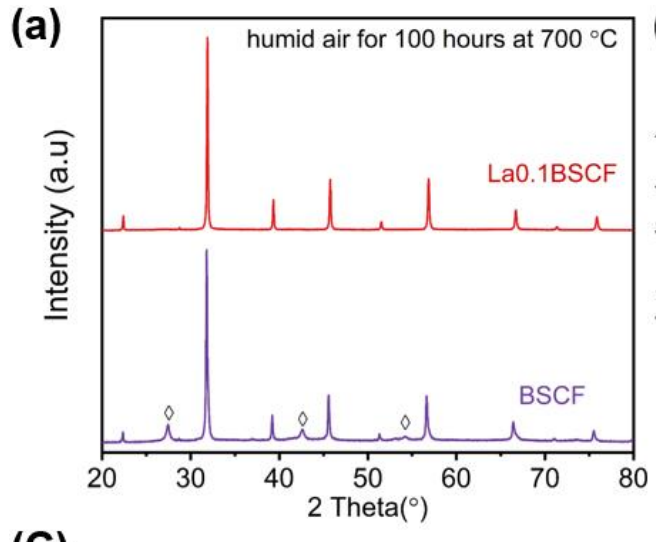

(C)

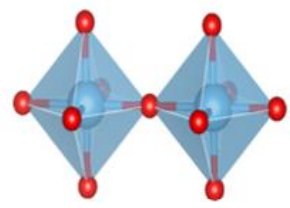

Figure $2 \mathrm{XRD}$ patterns of the BSCF, and $\mathrm{La} 0.1 \mathrm{BSCF}$ powder heat treated (a) in humid air at $700{ }^{\circ} \mathrm{C}$ for 100 hours, and (b) in $10 \% \mathrm{H}_{2} \mathrm{O}$ and $90 \% \mathrm{~N}_{2}$ at $700{ }^{\circ} \mathrm{C}$ for 100 hours (hollow diamond: $\mathrm{BaCoO}_{3-\delta}$-based oxide); (c) a schematic diagram showing the structure transformation from the corner-shared cubic phase to the face-shared hexagonal phase.

One of the core concerns in practical applications of BSCF especially in PCFCs, is structure instability at operating temperatures $\left(500-700{ }^{\circ} \mathrm{C}\right)(25,26)$. Figure $2 \mathrm{a}$ and $2 \mathrm{~b}$ present the XRD patterns for the La0.1BSCF and BSCF powder after heat treated at 700 ${ }^{\circ} \mathrm{C}$ in either humid air $\left(3 \% \mathrm{H}_{2} \mathrm{O}\right)$ or $10 \% \mathrm{H}_{2} \mathrm{O}-90 \% \mathrm{~N}_{2}$ for 100 hours. In the case of $\mathrm{BSCF}$, we find some extra peaks corresponding to a hexagonal structure (barium cobaltate based oxide) in both XRD patterns treated in the two atmospheres (16). This transformation blocks the application of BSCF. For La0.1BSCF, no extra peaks corresponding to the secondary phase are observed, suggesting much improved structure stability of La0.1BSCF in $\mathrm{H}_{2} \mathrm{O}$ or $\mathrm{CO}_{2}$ containing atmospheres due to introduction of $\mathrm{La}^{3+}$ into the BSCF lattice. Such improvement may be attributed to the fact that the interaction between La-O $(799 \mathrm{~kJ}$ $\left.\mathrm{mol}^{-1}\right)$ is much stronger than that of Ba-O $\left(563 \mathrm{~kJ} \mathrm{~mol}^{-1}\right)$. This is believed to inhibit oxygen releasing from the crystal lattice, and prevent the transformation of the corner-shared cubic structure to the face-shared hexagonal structure (22) as shown in Figure 2c. However, it should be noted that much stronger interaction between metal and oxygen is not conducive to the bulk transport of oxygen ions. Figure 3 a shows the $\mathrm{O}_{2}$-TPD profiles measured from $200{ }^{\circ} \mathrm{C}$ to $1000{ }^{\circ} \mathrm{C}$. The oxygen desorption peaks can be classified into two types, which 
are denoted as $\alpha$ at intermediate temperature $\left(300-600^{\circ} \mathrm{C}\right)$ and $\beta$ at elevated temperature (about $800{ }^{\circ} \mathrm{C}$ ), respectively. The $\alpha$ desorption is usually ascribed to a valence change from $\mathrm{Co}^{4+} / \mathrm{Fe}^{4+}$ to $\mathrm{Co}^{3+} / \mathrm{Fe}^{3+}$, and meanwhile, the oxygen species $\left(\mathrm{O}^{-}\right)$accommodated on the surface desorb. The $\beta$ desorption is associated with further decrease of valence from $\mathrm{Co}^{3+} / \mathrm{Fe}^{3+}$ to $\mathrm{Co}^{2+} / \mathrm{Fe}^{2+}$, and lattice oxygen $\left(\mathrm{O}^{2-}\right)$ desorbs from lattice. In Figure 3a, we can find that $\alpha$ desorption peak splits due to the different interactions between cobalt-oxygen and iron-oxygen, and there is little difference in $\alpha$ desorption peaks between BSCF and $\mathrm{La} 0.1 \mathrm{BSCF}$. However, the $\beta$ desorption of $\mathrm{La} 0.1 \mathrm{BSCF}$ is clearly smaller than that of BSCF, which may account for the improved stability due to the $\mathrm{La}^{3+}$ doping. Figure $3 \mathrm{~b}$ is the result of $\mathrm{CO}_{2}$-TPD. Due to the decrease in barium concentration, La0.1BSCF presents lower alkalinity, and thus a reduced $\mathrm{CO}_{2}$ desorption at lower temperature $(14,27)$.
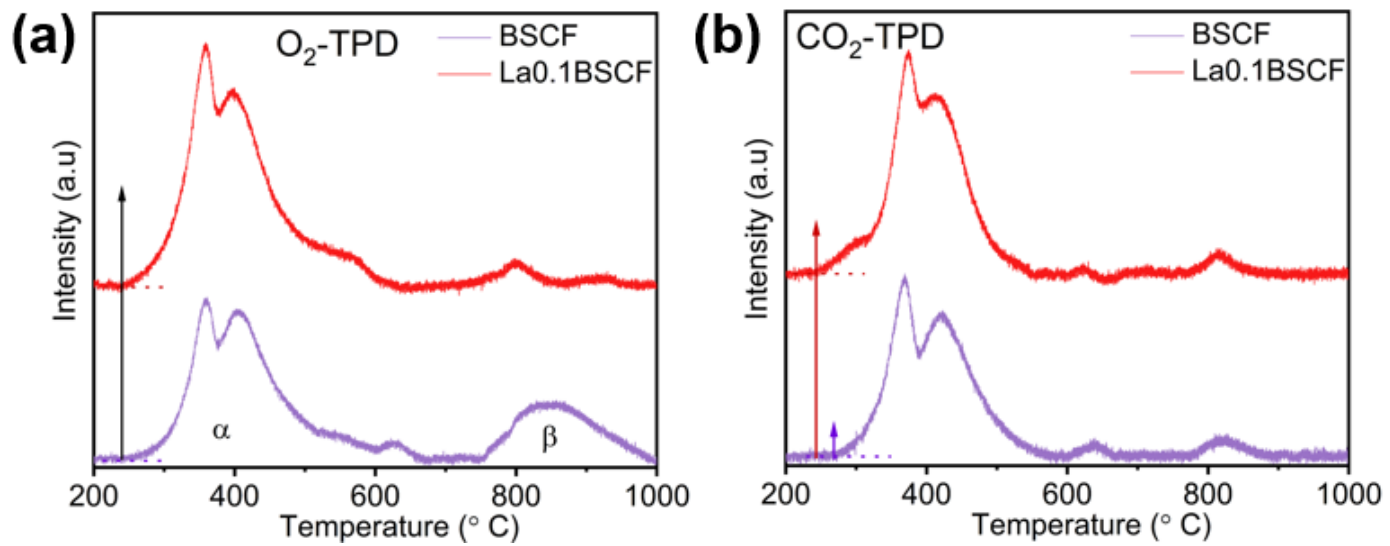

Figure 3 (a) $\mathrm{O}_{2}$-TPD and (b) $\mathrm{CO}_{2}$-TPD for BSCF and La0.1BSCF from 200 to $1000{ }^{\circ} \mathrm{C}$.

\section{$\underline{3.2 \text { Physicochemical Properties }}$}

As a promising cathode, good electrical conductivity is appreciated for current collection. Figure 4a plots the electrical conductivities of BSCF and La0.1BSCF at 550 $700{ }^{\circ} \mathrm{C}$ in air and pure oxygen. The conductivities of the two samples decrease with temperatures in both atmospheres. Moreover, La0.1BSCF displays a significantly improved conductivity by introducing $\mathrm{La}^{3+}$, which are 71.2 and $101.6 \mathrm{~S} \mathrm{~cm}^{-1}$ at $700{ }^{\circ} \mathrm{C}$ in air and pure oxygen, respectively, almost twice of those for BSCF $\left(34.7\right.$ and $50.19 \mathrm{~S} \mathrm{~cm}^{-}$ $\left.{ }^{1}\right)$. As Mathi Jaya et al. reported, the electron transport in the perovskite structure $\left(\mathrm{ABO}_{3}\right)$ is determined by double exchange between oxygen ions and B-site metals, which can be written as B-O-B (28). Introducing lanthanum reduces the lattice parameter of BSCF, which is beneficial to the electron transport. However, the strong interaction between lanthanum and oxygen ions may affect the hybridization of oxygen ions with $\mathrm{Co} / \mathrm{Fe}(29)$, which has an important effect on the conductivity and other properties of BSCF. 

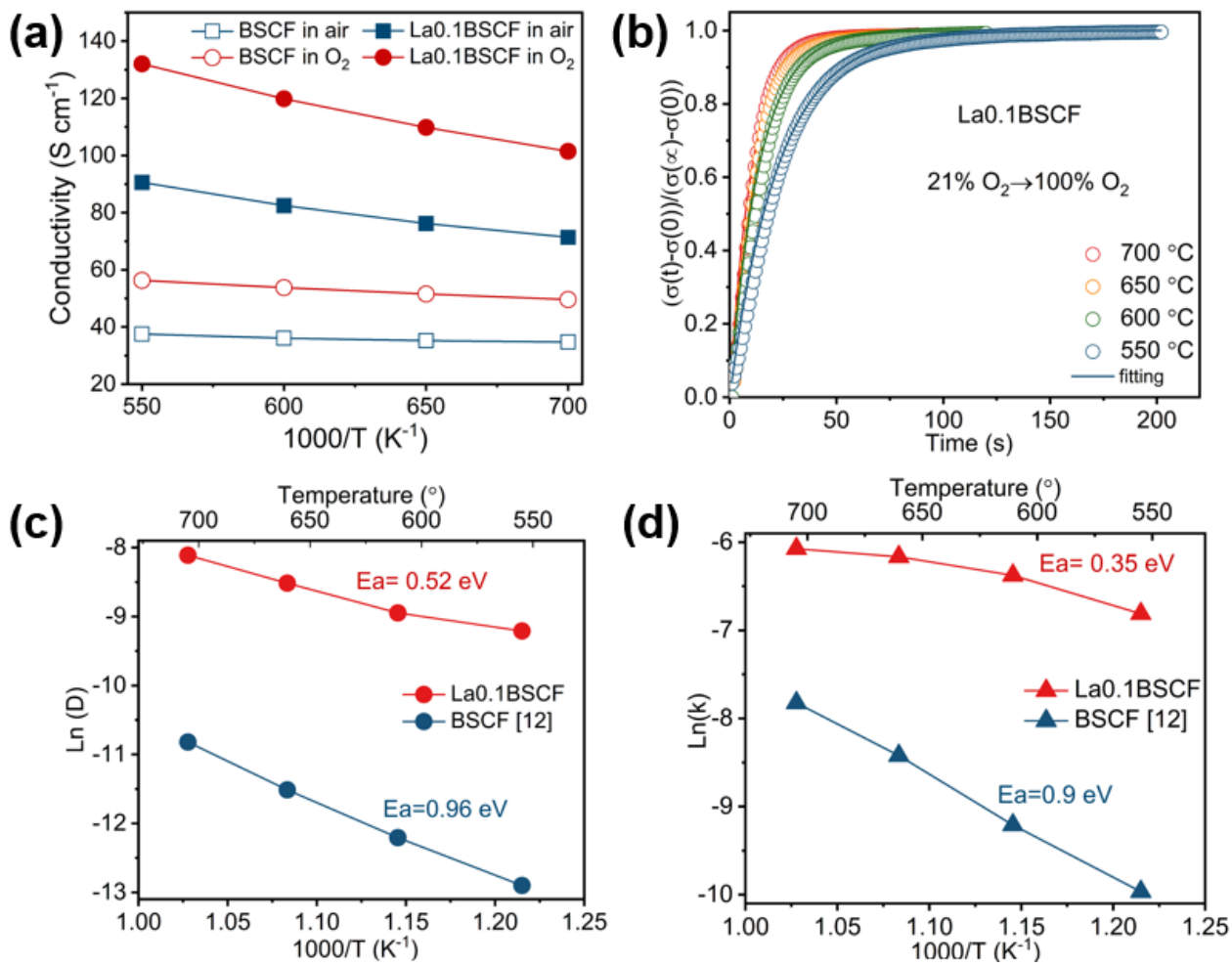

Figure 4 (a) Conductivity of BSCF and La0.1BSCF measured from 550 to $700{ }^{\circ} \mathrm{C}$ in air and pure oxygen. (b) Normalized conductivities of La0.1BSCF at different temperatures. Temperature dependence of (c) $D_{\text {chem }}$ and (d) $k_{\text {chem }}$ for La0.1BSCF and BSCF.

Oxygen transport properties are important for proton conducting cathode materials, as they will affect the catalytic activity toward oxygen reduction reaction (ORR), the recovery of surface active sites, and so on (12). In this work, the electrical conductivity relaxation (ECR) technique is used to explore the effect of lanthanum on the oxygen transport properties. Figure $4 \mathrm{~b}$ reveals time evolution of the normalized conductivity for La0.1BSCF measured at $550-700{ }^{\circ} \mathrm{C}$. The chemical oxygen surface exchange coefficient, $k_{c h e m}$, and chemical oxygen bulk diffusion coefficient, $D_{\text {chem }}$, are the main parameters to evaluate oxygen transport properties, and they can be obtained by fitting the normalized conductivities to Fick's second law. Figure $4 \mathrm{c}$ and $4 \mathrm{~d}$ present the fitting results and corresponding activation energy for La0.1BSCF, where the results for BSCF have been published in our previous work (12). For both BSCF and La0.1BSCF, $D_{\text {chem }}$ and $k_{\text {chem }}$ increase with increasing temperature, but La0.1BSCF shows smaller activation energies, $0.52 \mathrm{eV}$ for $D_{\text {chem }}$ and $0.35 \mathrm{eV}$ for $k_{\text {chem }}$, as compared with those for BSCF (about $0.96 \mathrm{eV}$ for $D_{\text {chem }}$ and $0.9 \mathrm{eV}$ for $k_{\text {chem }}$ ). In addition, La0.1BSCF always demonstrates good properties superior to BSCF, for example about $3 * 10^{-4} \mathrm{~cm}^{2} \mathrm{~s}^{-1}$ and $2.3 * 10^{-3} \mathrm{~cm} \mathrm{~s}^{-1}$ at 700 ${ }^{\circ} \mathrm{C}$ for $D_{\text {chem }}$ and $k_{\text {chem }}$, respectively. It should be noted that the bulk transport is related to not only the interaction between metal and oxygen ions, but also the free volume (30). We used the Rietveld refinement method to obtain the lattice parameters, and calculated the free volume. For La0.1BSCF, the free volume is calculated to be about $16.6263 \AA^{3}$, larger than that for BSCF $\left(12.6659 \AA^{3}\right.$ ). This may account for the larger $D_{\text {chem }}$ of La0.1BSCF as compared to that of BSCF. 

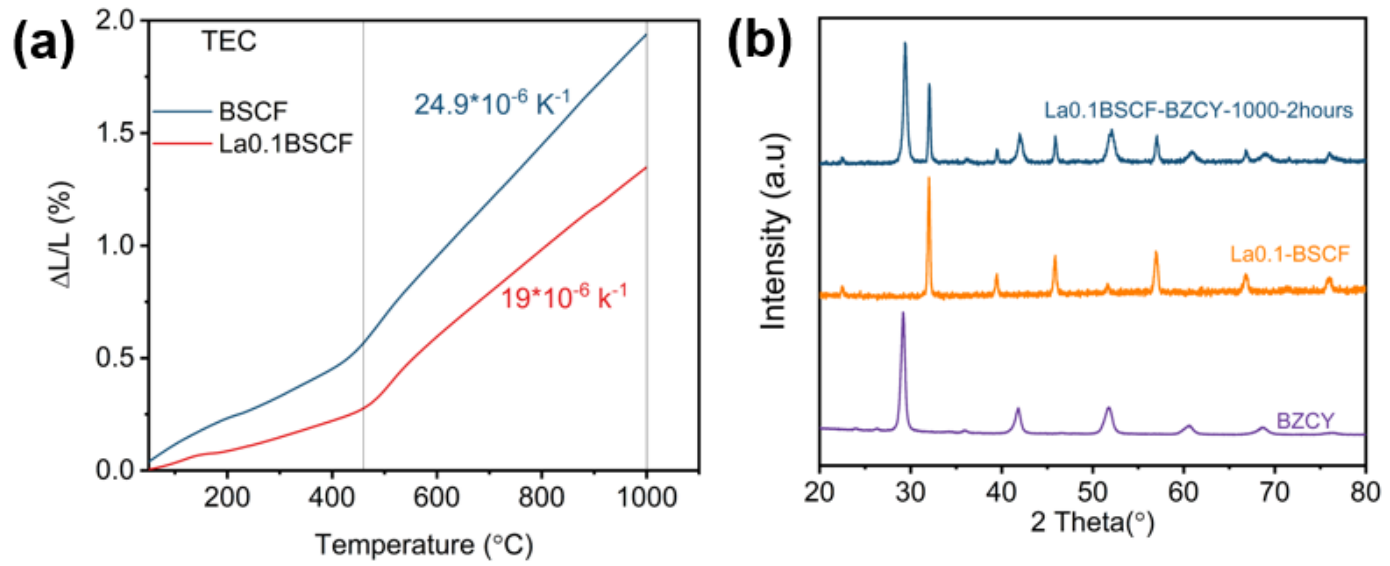

Figur 5 (a) Thermal expansion of BSCF and La0.1BSCF from room temperature to 1000 ${ }^{\circ} \mathrm{C}$; and (b) XRD measurements showing the chemical compatibility between BSCF and La0.1BSCF.

Large thermal mismatch between the electrode and electrolyte will cause serious performance degradation. Especially, cobalt-based perovskites often suffer from high thermal expansion coefficient (TEC) due to change of cobalt electronic structure and formation of oxygen vacancies (14). Before preparing single cells, dilatometry experiments with strip samples were conducted to evaluate the thermal expansion behavior of BSCF and La0.1BSCF (Figure 5a). The TEC for BSCF is calculated as $24.9 * 10^{-6} \mathrm{k}^{-1}$ between 450 - $1000{ }^{\circ} \mathrm{C}$, consistent with previously reported (31). La0.1BSCF exhibits a smaller TEC of $19^{*} 10^{-6} \mathrm{k}^{-1}$, closer to that of electrolyte materials, such as $11.2^{*} 10^{-6} \mathrm{k}^{-1}$ for BZCY (32). To investigate the chemical compatibility between La0.1BSCF and BZCY, the two powders were mixed in a weight ratio of $6: 4$, and then calcined at $1000{ }^{\circ} \mathrm{C}$ in air for 2 hours. As shown in Figure 5b, all the diffraction peaks for the mixed sample can be indexed to either La0.1BSCF or BZCY, indicating good chemical compatibility between La0.1BSCF and BZCY under operating conditions.

\section{$\underline{3.3 \text { Electrochemical Performance }}$}

Single cells with the NiO-BZCY anode substrate were used to further evaluate the performance of the La0.1BSCF cathode. Figure 6c shows the cross-section morphology of our manufactured single cell, showing a dense electrolyte and the two porous electrodes attached well to the electrolyte. $I-V$ - $P$ curves and EIS spectra of the single cells are presented in Figure $6 \mathrm{a}$ and $6 \mathrm{~b}$, measured at different temperatures with humid hydrogen $\left(3 \% \mathrm{H}_{2} \mathrm{O}\right)$ to the anode and ambient air to the cathode. The cell shows a peak power density of about 650 and $350 \mathrm{~mW} \mathrm{~cm}^{-2}$ at 700 and $600{ }^{\circ} \mathrm{C}$, respectively. These values are higher than those previously reported under similar configuration and test conditions, such as $\sim 430 \mathrm{~mW} \mathrm{~cm}^{-2}$ at $700{ }^{\circ} \mathrm{C}$ with BSCF- $\mathrm{BaZr}_{0.1} \mathrm{Ce}_{0.7} \mathrm{Y}_{0.2} \mathrm{O}_{3-\delta}$ cathode (33), $290 \mathrm{~mW} \mathrm{~cm}{ }^{-2}$ at $600{ }^{\circ} \mathrm{C}$ with $\mathrm{BSCF}-\mathrm{BaCe}_{0.6} \mathrm{Zr}_{0.2} \mathrm{Y}_{0.2} \mathrm{O}_{3-\delta}$ cathode (34), and $\sim 340 \mathrm{~mW} \mathrm{~cm}{ }^{-2}$ at $700{ }^{\circ} \mathrm{C}$ with $\mathrm{La}_{0.6} \mathrm{Sr}_{0.4} \mathrm{Co}_{0.2} \mathrm{Fe}_{0.8} \mathrm{O}_{3}$ (LSCF)- $\mathrm{BaCe}_{0.8} \mathrm{Sm}_{0.2} \mathrm{O}_{2.9}$ (35). Our cell shows an ohmic resistance of $0.31 \Omega \mathrm{cm}^{2}$ and a polarization resistance of $0.05 \Omega \mathrm{cm}^{2}$ at $700{ }^{\circ} \mathrm{C}$ demonstrating well prepared single cells. Considering the relatively large ohmic resistance, the cell performance can be further improved by optimizing the preparation process or reducing the electrolyte thickness. Our findings confirm the potential application of La0.1BSCF as highly efficient and stable cathode material for PCFCs. 


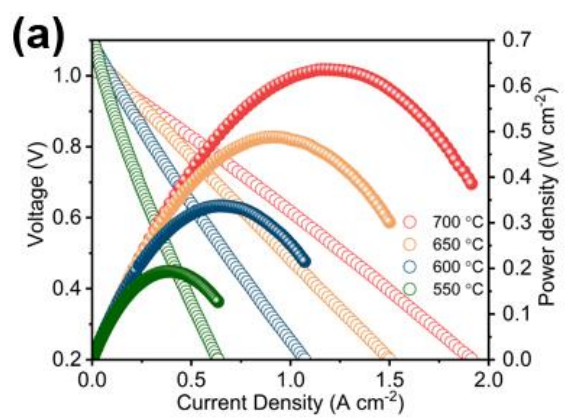

(b)

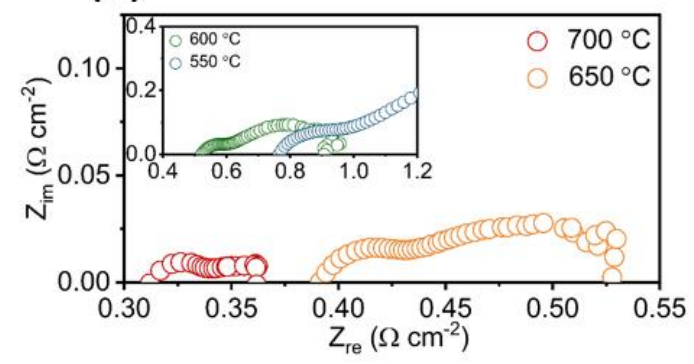

(c)

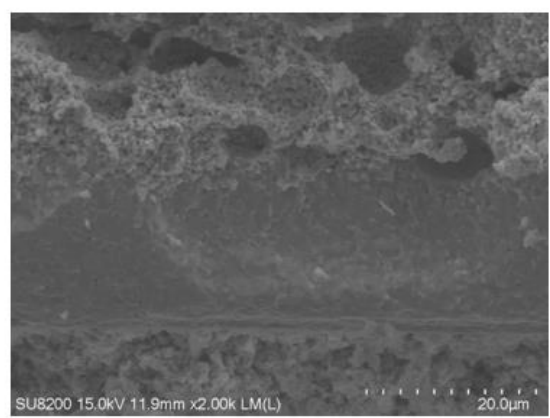

Figure 6 (a) $I-V$-P curves and (b) EIS results at different temperature with hydrogen as fuel and ambient air as oxidant; (c) Cross-section morphology of the prepared single cells.

\section{Conclusion}

In summary, our $\mathrm{XRD}, \mathrm{O}_{2}$-TPD and $\mathrm{CO}_{2}$-TPD results show that introducing lanthanum into the BSCF crystal lattice successfully improves the structure stability by inhibiting lattice oxygen release and decreasing the adsorption strength of $\mathrm{CO}_{2}$. The higher bonding energy of La-O contributes to increased conductivity and oxygen reduction reaction, as revealed by the ECR measurement. La doping reduces thermal expansion coefficient as revealed by the dilatometry experiments, ensuring a better mechanical match with the BZCY electrolyte. Employing such material as the cathode of single cells, the manufactured PCFCs present a low polarization resistance about $0.05 \Omega \mathrm{cm}^{2}$ at OCV, and a peak power density of $650 \mathrm{~mW} \mathrm{~cm}^{-2}$, at $700{ }^{\circ} \mathrm{C}$. Our work demonstrates the La doped $\mathrm{BSCF}$ is a promising cathode for PCFCs.

\section{Acknowledgments}

This work was financially supported by the Natural Science Foundation of China (51872276) and the National Key Research and Development Program of China (2017YFA0402800).

\section{References}

1. C. Duan, J. Huang, N. Sullivan, R. O'Hayre, Appl. Phys. Rev., 7(1), 011314 (2020).

2. Y. Zhou, E. Liu, Y. Chen, Y. Liu, L. Zhang, W. Zhang, Z. Luo, N. Kane, B. Zhao, L. Soule, Y. Niu, Y. Ding, H. Ding, D. Ding, M. Liu, ACS Energy Lett., 6(4) ,1511 (2021).

3. D. Huan, L. Zhang, X. Li, Y. Xie, N. Shi, S. Xue, C. Xia, R. Peng, Y. Lu, ChemSusChem, 13(18), 4994 (2020). 
4. J. H. Kim, S. Yoo, R. Murphy, Y. Chen, Y. Ding, K. Pei, B. Zhao, G. Kim, Y. Choi, M. Liu, Energy Environ. Sci., 14(3), 1506 (2021).

5. R. Peng, T. Wu, W. Liu, X. Liu, G. Meng, J. Mater. Chem, 20(30), 6235 (2010).

6. L. Bi, S. Boulfrad, E. Traversa, Chem Soc Rev, 43(24), 8255 (2014).

7. D. Pergolesi, E. Fabbri, A. D’Epifanio, E. Di Bartolomeo, A. Tebano, S. Sanna, S. Licoccia, G. Balestrino, E. Traversa, Nat. Mater., 9(10), 846 (2010).

8. E. Fabbri, A. Depifanio, E. Dibartolomeo, S. Licoccia, E. Traversa, Solid State Ionics, 179(15-16), 558 (2008).

9. E. Fabbri, D. Pergolesi, E. Traversa, Chem Soc Rev, 39(11), 4355 (2010).

10. L. Yang, S. Wang, K. Blinn, M. Liu, Z. Liu, Z. Cheng, M. Liu, Science, 326(5949), $126(2009)$.

11. Z. Shao, S. M. Haile, J. Ahn, P. D. Ronney, Z. Zhan, S. A. Barnett, Nature, 435(7043), 795 (2005).

12. Y. Xie, N. Shi, D. Huan, W. Tan, J. Zhu, X. Zheng, H. Pan, R. Peng, C. Xia, ChemSusChem, 11(19), 3423 (2018).

13. B. Hu, C. Xia, Asia-Pac. J. Chem. Eng., 11(3), 327 (2016).

14. Y. Wan, Y. Xing, Y. Li, D. Huan, C. Xia, J. Power Sources, 402, 363 (2018).

15. L. Almar, H. Störmer, M. Meffert, J. Szász, F. Wankmüller, D. Gerthsen, E. IversTiffée, ACS Appl. Energy Mater, 1(3), 1316 (2018).

16. D. N. Mueller, R. A. De Souza, T. E. Weirich, D. Roehrens, J. Mayer, M. Martin, Phys Chem Chem Phys, 12(35), 10320 (2010).

17. A. Yan, M. Cheng, Y. Dong, W. Yang, V. Maragou, S. Song, P. Tsiakaras, Appl. Catal., $B, 66(1-2), 64$ (2006).

18. A. Yan, M. Yang, Z. Hou, Y. Dong, M. Cheng, J. Power Sources, 185(1), 76 (2008).

19. N. Tsvetkov, Q. Lu, L. Sun, E. J. Crumlin, B. Yildiz, Nat. Mater., 15(9), 1010 (2016).

20. L. Lei, J. Zhang, Z. Yuan, J. Liu, M. Ni, F. Chen, Adv. Funct. Mater., 29(37), 1903805 (2019).

21. M. Steven, F. V. Jaap, G. H. Wim, Dave H.A. Blank., Henny J.M. B., Solid state Ionics 177, 833 (2006).

22. Z. Chen, W. Wang, Y. Yang, H. Tang, Z. Sun, J. Wang, H. Huang, R. Peng, Z. Fu, Y. Lu, Chem. Mater., 31(22), 9453 (2019).

23. Y. Xie, N. Shi, X. Hu, M. Liu, Y. Yang, D. Huan, Y. Pan, R. Peng, C. Xia, Int. J. Hydrogen Energy, 45(20), 11791 (2020).

24. N. Shi, F. Su, D. Huan, Y. Xie, J. Lin, W. Tan, R. Peng, C. Xia, C. Chen, Y. Lu, J. Mater. Chem. A, 5(37), 19664 (2017).

25. C. Niedrig, S. Taufall, M. Burriel, W. Menesklou, S. F. Wagner, S. Baumann, E. IversTiffée, Solid State Ionics, 197(1), 25 (2011).

26. S. Svarcova, Solid State Ionics, 178(35-36), 1787 (2008).

27. Z. Shao, W. Yang, Y. Cong, H. Dong, J. Tong, G. Xiong, J. Membr. Sci., 172(1-2), 177 (2000).

28. S. Mathi Jaya, R. Jagadish, R. S. Rao, R. Asokamani, Phys Rev B Condens Matter, 43(16), 13274 (1991).

29. X. Hu, Y. Xie, Y. Wan, Y. Yang, X. Wu, C. Xia, Appl. Catal., B, 286, 119901 (2021).

30. S. Carter, A. Selcuk, R. Chater, J. Kajda, J. Kilner, B. Steele, Solid State Ionics, 53, 597 (1992).

31. B. Wei, Zh. Lü, Sh. Li, Y. Liu, K. Liu, and W. Su, Electrochem. Solid-State Lett., 8(8), A428 (2005).

32. S. Yamanaka, M. Fujikane, T. Hamaguchi, H. Muta, T. Oyama, T. Matsuda, S.-i. Kobayashi, K. Kurosaki, J. Alloys Compd., 359(1-2), 109 (2003). 
33. B. Lin, H. Ding, Y. Dong, S. Wang, X. Zhang, D. Fang, G. Meng, J. Power Sources, 186(1), 58 (2009).

34. Y. Lin, R. Ran, Y. Guo, W. Zhou, R. Cai, J. Wang, Z. Shao, Int. J. Hydrogen Energy, 35(7), 2637 (2010).

35. F. Su, C. Xia, R. Peng, J. Eur. Ceram. Soc., 35(13), 3553 (2015). 